\title{
INCIDENCE OF PHLEBITIS FOLLOWING THE USE OF PERIPHERAL IV LINE AT X HOSPITAL
}

\author{
Margareta Sijabat ${ }^{1}$, Sisilia Desiana Nduru², Ayu Monaretha B ${ }^{3}$, Yenni Ferawati \\ Sitanggang ${ }^{4}$, and Elissa Oktoviani Hutasoit ${ }^{5}$
}

1,2,3 Student of Faculty of Nursing, University of Pelita Harapan, Indonesia

${ }^{4}$ Faculty of Nursing, University of Pelita Harapan, Indonesia

5 Clinical Educator of Faculty of Nursing, University of Pelita Harapan, Indonesia

e-mail: yenni.sitanggang@uph.edu

\begin{abstract}
Introduction: Intravenous (IV) line infusion therapy is a therapy given to patients who are admitted or having a specific therapy. The IV-line therapy may include fluid therapy, medication administration and blood therapy. Based on the data found in Hospital X, there were 30 incidence of phlebitis in 2017. This study aimed to describe the factors of phlebitis incidence in X hospital. Method: This study was a retrospective study using 50 clinical record of the inpatient patients. The inclusion criteria were all documents of those who are hospitalized at least three days. Result: The result describes three factors following the incidence of phlebitis, such as intrinsic factors, chemical factors, and mechanical factors. The Intrinsic factors included age, gender and medical diagnosis. While Mechanical factors consist of the size of catheter, location and length of infusion. The Chemical factors were of infusion fluid type and infusion rate. Conclusion: The conclusion of this study was the three factors are modifiable factors. Thus, nurses need to assess and evaluate patients' infusion in order to prevent a higher case of phlebitis. As a recommendation for further study is to analyze the correlation between those factors to the incidence of phlebitis.
\end{abstract}

Keywords: Phlebitis Incidence, Peripheral IV Line, IV Line Infusion

\section{INTRODUCTION}

Peripheral IV line is the most common invasive procedure implemented for patient who are hospitalized. The implementation of peripheral IV line needs to be done by competent nurses who are knowledgeable and skilful. This therapy brings so many advantages as it is used as an IV fluid therapy, medication administration and blood transfusion (Wayunah et al., 2013). Despite all advantages, the peripheral IV insertion can bring some drawback such as phlebitis. Nurses have to be clinically competent to choose the right location, right IV catheter and to perform the aseptic techniques before the IV-line insertion. Wrong IV catheter and location can bring harm to patients and lead to infection. Nurses should inserted the IV line correctly, in order to prevent any possible complications such as phlebitis or worsen patients' condition (Brunner, 2016).

Phlebitis is common complication which is caused by peripheral IV line or improper IV line application. According to Brunner, (2016), phlebitis is an irritation nor inflammation of the tunica intima, the internal lining of the vein which occurs due to complications of using peripheral IV line. During catheter insertion, microbes can emerge from patients' skin or contaminate from nurses' hands and might migrate down the catheter tract into the bloodstream (Ray-Barruel, 2017). Phlebitis can bring pain, discomfort, edema, erythema and hardening skin of the patients and also longer hospital stays.

A peripheral IV cannula has to be assessed using a PIVAS (Peripheral Intravenous Assessment Score) tools and has to be documented at least 
every eight to 72 hours or after the IV removal (Rizky, 2016). Phlebitis manifested in four grades; grade 1-

erythema at the IV site, pain and tenderness, grade 2-swelling, pain and erythema, grade 3-pain along cannula path, erythema, hardening and palpable venous cord, grade 4advanced stage of phlebitis and thrombophlebitis, grade 5-advanced stage of thrombophlebitis (Health Department of Government of Australia, 2017).

Study from Urbanetto et al., (2016) showed that 55\% respondents had grade two phlebitis after peripheral catheter removed and grade one phlebitis while peripheral catheter in place. Based on the data collection in X Hospital in 2017, there were 30 incidence of phlebitis per year. The highest incidence occurred in June with an Incident Rate of 7.3 per mil, this number was more than the hospital's indicator of 3.5 per mil. This data incident was taken from the patient's documentation who had phlebitis and PIVAS score above 1 . Phlebitis can be caused by several factors. Thus, this study aimed to identify the factors that contribute to the incidence of phlebitis in hospital $\mathrm{X}$.

\section{METHODS}

This study was a retrospective study which involved 50 patients' clinical record to collect data of phlebitis incidence. According to Nursalam (2015), a documentation study is a technique of collecting data either by documents to find the data or information related to the study. This study was conducted between June-July 2018 in the inpatient rooms at Hospital X.

This study used a purposive sampling of 50 inpatients clinical record with the following inclusion criteria; patients who have peripheral IV catheter during at least three days hospitalization as well as patients who were hospitalized less than three days with the PIVAS score 0 , patients who has medical diagnosis recorded and PIVAS score were recorded in the document. While the exclusion criteria were patient with the CVC (Central Venous Catheter) in place. This study was reviewed by Research Committee Training and Community Service (RCTC) of Universitas Pelita Harapan No. 001/RCTCEC/R/SHBTS/V/2018 and has granted permission from the Hospital.

\section{RESULTS}

A glance at the figure depicts the frequency of removing peripheral IV lines in hospital X. Table 1 shows that $64 \%$ patients with peripheral IV catheter developed phlebitis and that is why the IV catheter was removed. While $36 \%$ others were free from phlebitis and the IV catheter were removed due to discharge from hospital. Moreover, Table 1 shows that most of the patients had PIVAS score of 2 (34\%). However, 36\% patients from 50 documents analysed showed 0 for PIVAS score. Based on these 50 medical records, three factors were retrieved as causes of phlebitis, there are intrinsic factors, mechanical factors and chemical factors. Intrinsic factors are age, gender and medical diagnosis. The mechanical factors are IV catheter size, the location of the peripheral IV line, and the length of IV-line use. Moreover, chemical factors included fluid types and infusion speed rate. Below was the illustration of each factor from the medical records.

\section{Intrinsic Factors}

Figure 2 shows that majority of patients with IV catheter was male $(62 \%)$ and male respondents had the highest number of phlebitis incidence $(81 \%)$. Most of the respondents were adults. In addition, the frequency distribution of aged was illustrated in figure 3 , as classified into four stages; toddler, adolescent, adult, elderly 
and old age. Phlebitis mostly occurred in the elderly, over twenty percent. This study also showed that the other intrinsic factor that contribute to phlebitis is medical diagnoses. The highest was on diabetes mellitus patients compared to other medical diagnoses

\section{Mechanical Factors}

Based on mechanical factors, as can be seen in table figure $5 \&$ figure 6 , it can be explained that 20G Catheter was the most gauge used for patients $(50 \%)$ and has resulted in developing phlebitis too (36\%).
Moreover, the result showed that the most sites of the infusion were in the dorsal metacarpal area (64\%) and the duration of infusion was mostly on 24-72 hours.

\section{Chemical Factors}

Figure 7 below, described the types of fluids for infusion and the infusion speed. Isotonic $(56 \%)$ were the most given fluid and are the main cause of phlebitis $(26 \%)$ and following hypertonic fluid (24\%). While the infusion' rate on fast speed were almost the same risk of phlebitis

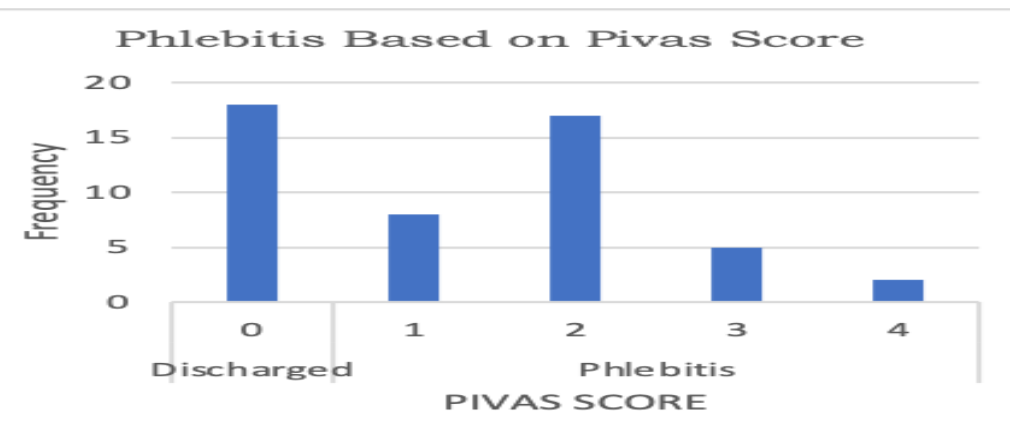

Figure 1. Phlebitis incidence based on PIVAS score

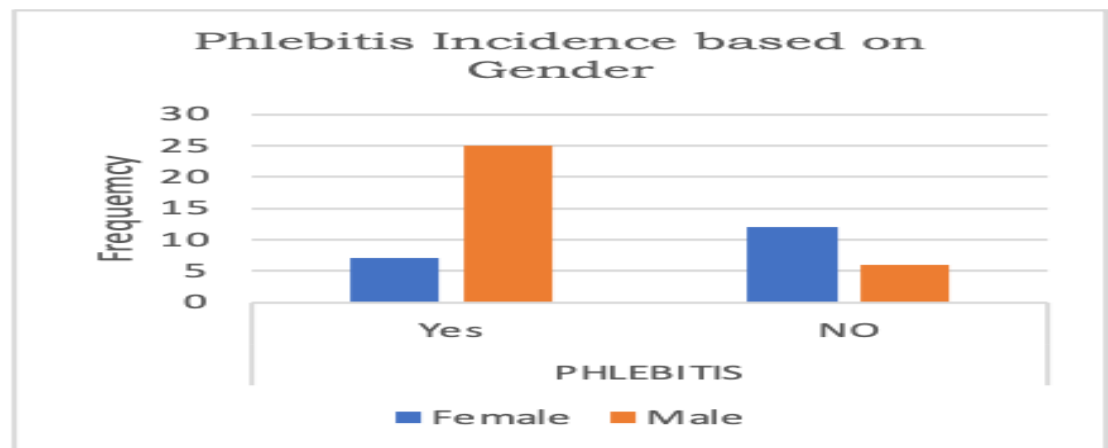

Figure 2. Phlebitis incidence based on gender

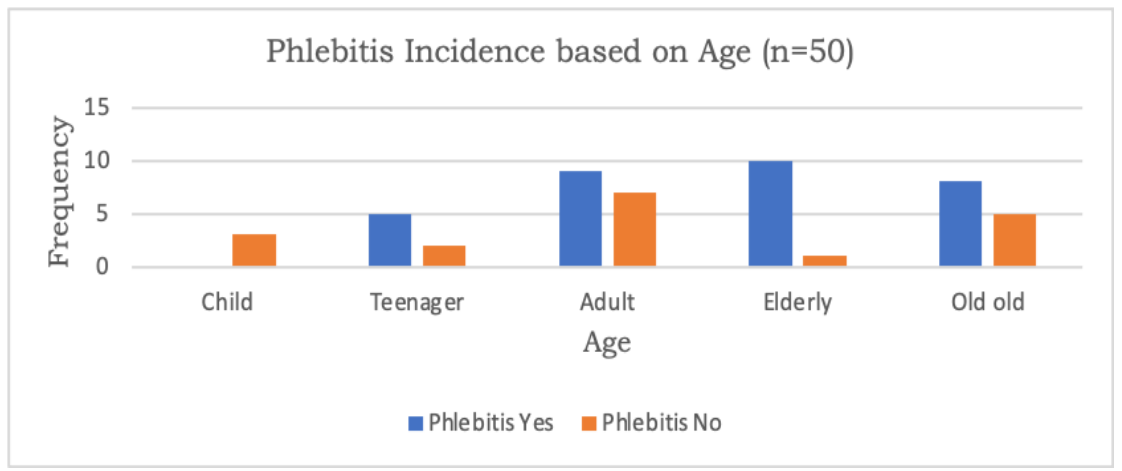

Figure 3. Phlebitis incidence based on age 


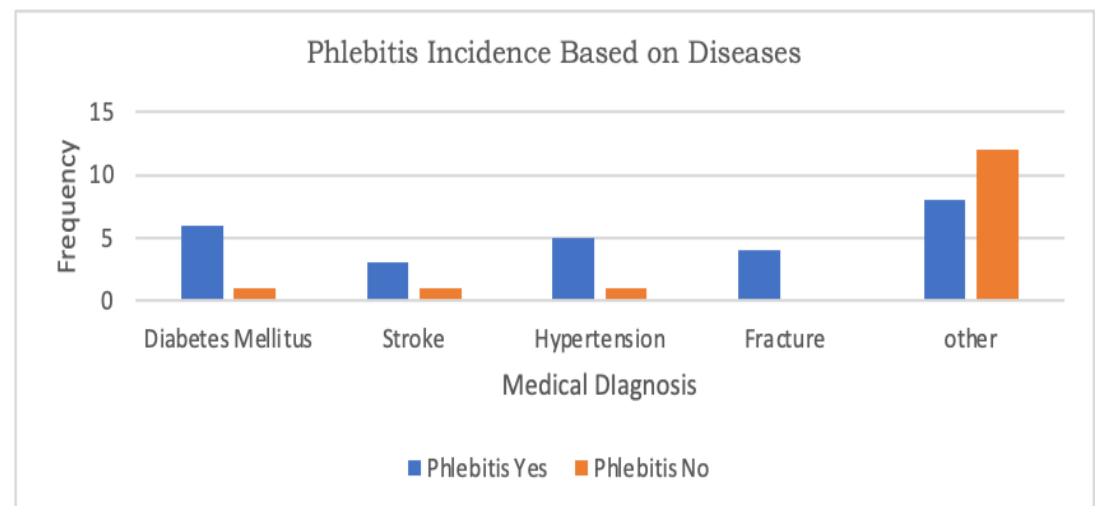

Figure 4. Phlebitis incidence based on medical diagnosis

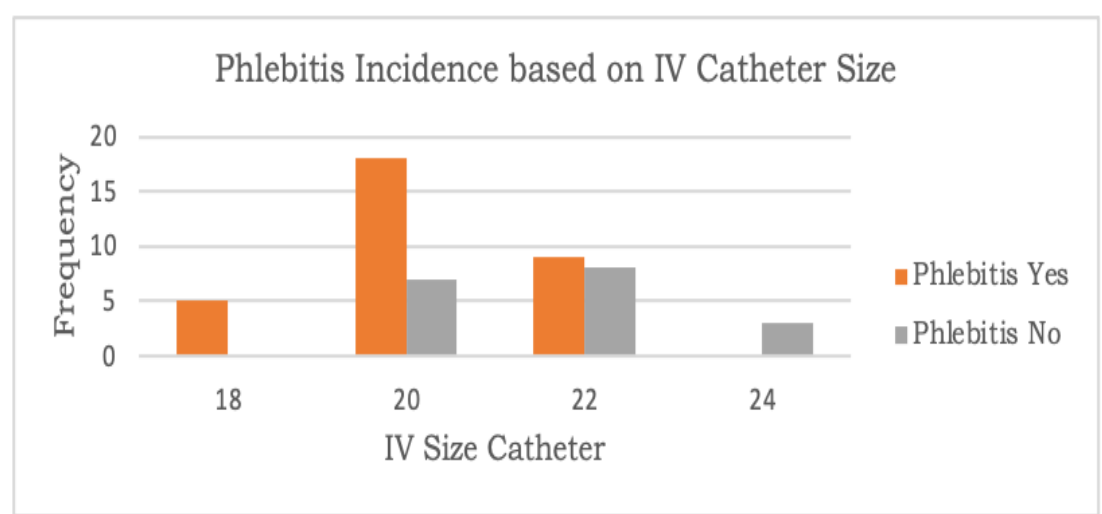

Figure 5. Frequency distribution of phlebitis incidence based on IV catheter size

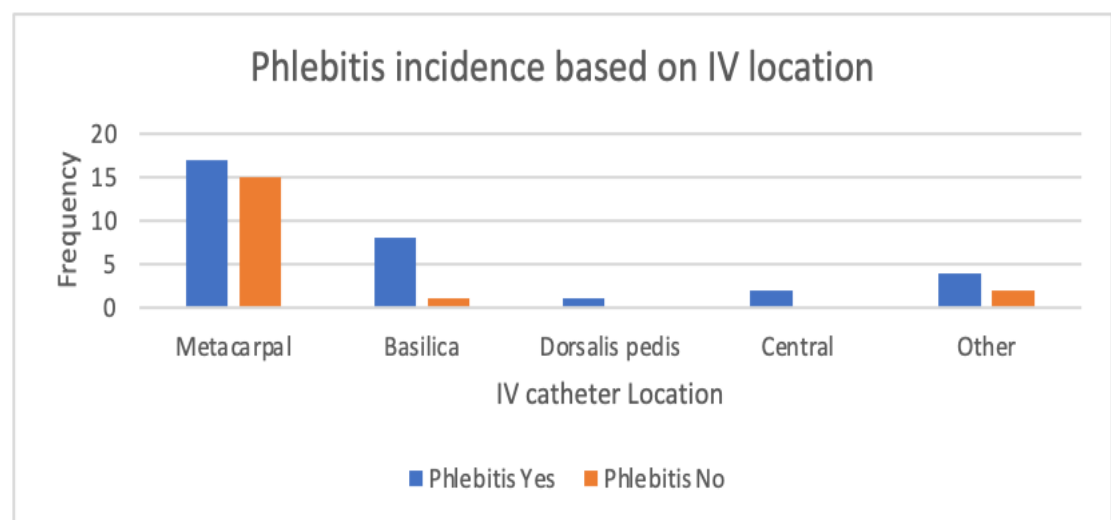

Figure 6. Distribution of phlebitis incidence based on IV catheter location

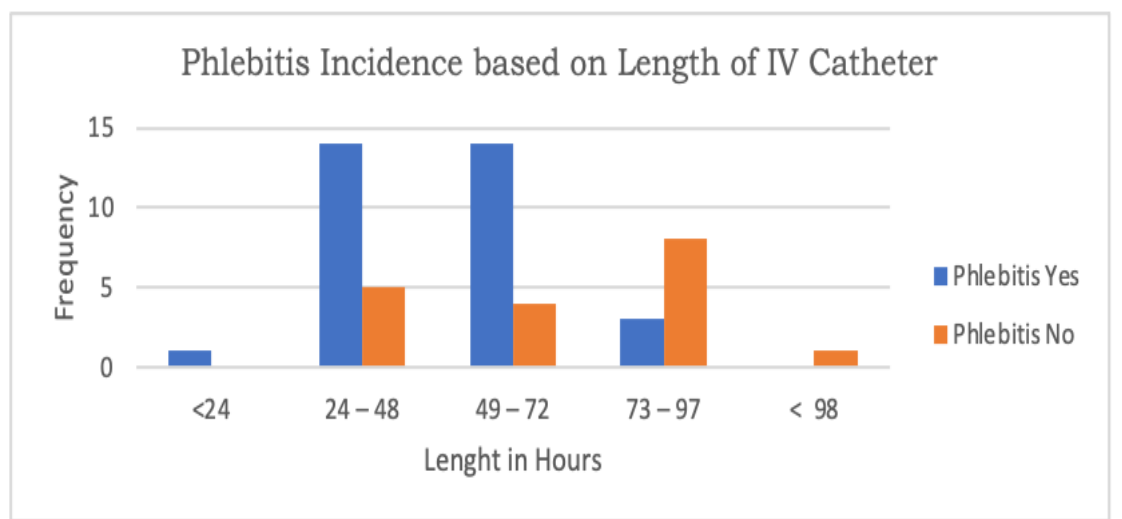

Figure 7. Distribution of phlebitis based on length of infusion 


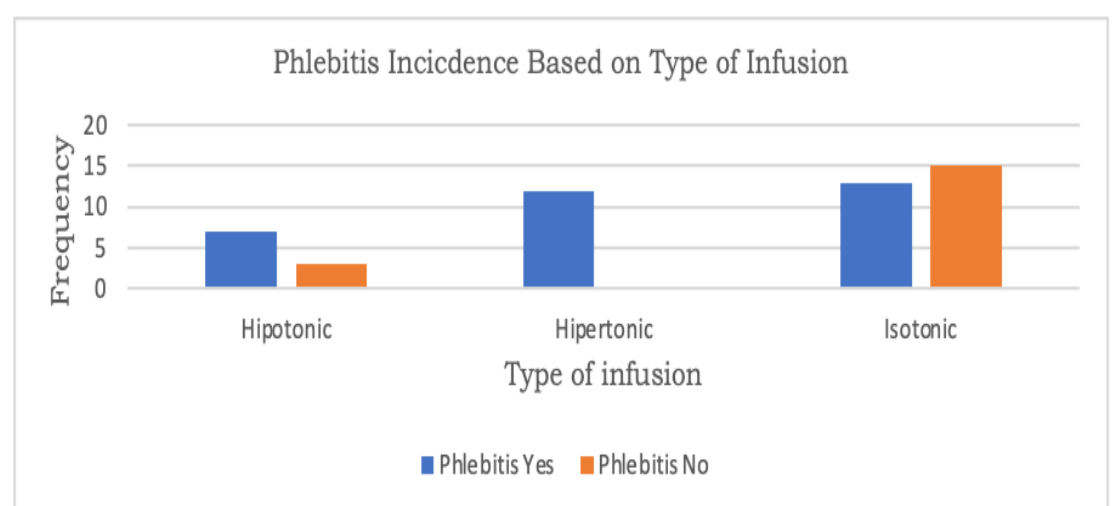

Figure 8. Distribution of phlebitis incidence based on type of infusion fluid

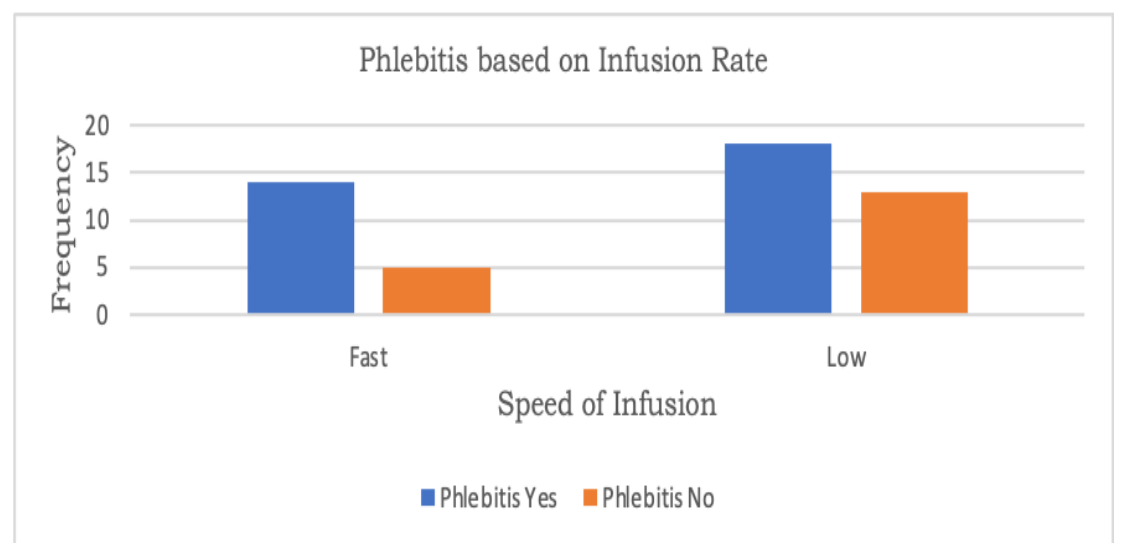

Figure 8. Distribution of phlebitis based on the infusion speed

\section{DISCUSSION}

Based on the data from total of 50 clinical record, $64 \%$ patients were recorded to develop phlebitis during hospitalization. The etiology of phlebitis is multifactorial, and it range from mild to severe condition. This study identifies three main factors that contribute to the incidence of phlebitis; intrinsic factors, mechanical factors and chemical factors.

\section{Intrinsic Factors}

In this study, the incidence of phlebitis is higher in male $(81 \%)$ as compare to female (37\%). This study is in line with the result from Mandal \& Raghu, (2019) \& Marleni et al., (2009) \& Nyika et al., (2018) who confirm that male might have a higher potential for getting phlebitis especially in an obese case and a smoker that was lead to the accumulation of fats and nicotine substances through the blood vessels. Therefore, it caused the blood vessels to more constrict, and was easier to experience phlebitis. Meanwhile, three studies Jannah et al., (2016), Mandal \& Raghu, (2019) \& (Do Rego Furtado, 2011) stated that phlebitis was mostly found in female. This may due to female's hormonal factors and also the size of female blood vessels which were smaller than males, as in males the blood vessels is larger and lack of fat deposits (Rizky, 2016). However, we did not analyze the association between gender and the incidence of phlebitis.

Age was also another intrinsic factor of phlebitis and has a significant relationship with the occurrence of phlebitis (Laudenbach et al., 2014). This statement supports the result of the recent study where elderly has the most cases of phlebitis $(20 \%)$. During this age, the level of movement and individual potency begins to decrease, leading to inflexibility of the blood vessels 
(Engbers et al., 2010). Nevertheless, age could not be generalized as the only predictor factor of phlebitis as it is important to consider the proper IV catheter based on the vein's characteristics. For example, if bigger catheter is used for small vein, it will irritate the vein wall (Hidayat et al., 2020). Therefore, nurses need to choose a proper and suitable IV gauge before the IV line applied.

\section{Mechanical Factors}

The incidence of phlebitis was shown to be higher in patients with $20 \mathrm{G}$ catheter in situ (36\%) and less in patients with $18 \mathrm{G}$ catheter (10\%). This findings coincide with the study conducted by Mandal \& Raghu, (2019), Rizky, (2016) \& Nyika et al., (2018). In contrast, previous study by Urbanetto et al., (2016) informed that the incidence of phlebitis was higher to those patients with $18 \mathrm{G}$ catheter compared to patients with the $20 \mathrm{G}$ needle. Nevertheless, they added that there was no relationship between catheter's number used and the incidence of phlebitis or the grade of phlebitis. However, choosing the right cannula can help to maintain the blood flow around the cannula and it is effective to prevent the existence of inflammation (Fatimah, 2016). Though there were still small amount of patients who had phlebitis on $22 \mathrm{G}$ gauge catheter, it is recommended to use a smaller catheter as it will allow blood to flow in the adjacent tissue and prevent damage to vein (Joae Brett Nito et al., 2017; O'Grady et al., 2011). Above all, it also depends on the infusion type, thicken fluid such as antibiotics and chemotherapy drugs with high osmolarity will need bigger IV catheter. To reduce the risk of phlebitis (Singh et al., 2018).

Phlebitis also develops to those patients who had infusion between $24-48(38 \%)$ and $49-72$ hours (36\%). The length of more than 72 hours catheter in situ shows sign and symptoms of phlebitis (Nyika et al., 2018; Urbanetto et al., 2016). Most of the location used was metacarpal $(64 \%)$. This location allows patients to move freely and it is easy to be seen and palpated (Potter \& Perry, 2010). However, this might be disadvantage for patients who are very active, as it may shift the catheter and caused phlebitis. As mentioned by Health Department of Government of Australia, (2017) that metacarpal area is very close to wrist so when the extremity moves, it makes backflow of the blood and causes trauma to the vein. The choice of location determined by preferences, habits, personal expertise and also the quality of vein. As a consequent, nurses required to choose a proper area that can lessen the risk of phlebitis. As suggested by Cicolini in their study that the use of antecubital fossa and forearm veins reduce the risk of phlebitis up to $40 \%$ (Cicolini et al., 2014).

\section{Chemical Factors}

Nurses must consider the osmolality of a solution therapy (Marleni et al., 2009). There are three types of osmolality solution such as isotonic (280-300 mOsm / L), hypotonic (<280 mOsm / L), and hypertonic (> 300 mOsm / L) (Brunner, 2016). Both isotonic and hypertonic solutions cause phlebitis in this study. However, all patients who had hypertonic solution were all had phlebitis while more patients in isotonic free from phlebitis. According to Joae Brett Nito et al., (2017) there was a significant association between osmolarity with the incidence of phlebitis. Hypertonic has higher osmolarity than isotonic, thus it increases the risk of phlebitis. As study from Do Rego Furtado, (2011), higher phlebitis occurred in patients who received antibiotics, as it highly irritates to the blood vessels. We also found in the clinical record that infusion rate is another factor that can contribute to phlebitis. This is similar to studies by Do Rego Furtado, (2011; Nyika et al., (2018) that 
highlighted continuous infusion as a predictor of phlebitis. Therefore, nurses have to evaluate catheter insertion regularly by palpating through dressing and inspecing sign of phlebitis (Singh et al., 2018). If patients develop the signs, then peripheral IV catheter has to be replaced.

\section{CONCLUSION}

The incidence of phlebitis might be caused by modifiable factors like catheter's size, rate of infusion, type of solution, IV location and length of IV catheter used. To reduce the number of incidence, it is important to improve care for enhancing patients' comfort. Analyze correlation of factors towards phlebitis incidence is recommended for further study.

\section{REFERENCES}

Brunner, S. (2016). Buku Ajar Keperawatan Medikal Bedah Brunner \& Suddarth edisi 8 Volume 1,2. Jakarta: penerbit Buku Kedokteran Indonesia EGC. Water (Switzerland).

Cicolini, G., Manzoli, L., Simonetti, V., Flacco, M. E., Comparcini, D., Capasso, L., Di Baldassarre, A., \& Eltaji Elfarouki, G. (2014). Phlebitis risk varies by peripheral venous catheter site and increases after 96 hours: A large multicentre prospective study. Journal of Advanced https://doi.org/10.1111/jan.12403

Do Rego Furtado, L. C. (2011). Incidence and predisposing factors of phlebitis in a surgery department. British Journal of Nursing.

https://doi.org/10.12968/bjon.2011.20. sup7.s16

Engbers, M. J., van Hylckama Vlieg, A., \& Rosendaal, F. R. (2010). Venous thrombosis in the elderly: Incidence, risk factors and risk groups. In Journal of Thrombosis and Haemostasis. https://doi.org/10.1111/j.15387836.2010.03986.x

Fatimah, S. H. \& S. (2016). Faktor yang berhubungan dengan kejadian phlebitis di ruang anak RSUD DR. R. Soetrasno Rembang. Motorik.

Health Department of Government of Australia. (2017). Insertion and Management of Peripheral Intravenous Cannulae in Western Australian Healthcare Facilities Policy. https://ww2.health.wa.gov.au/-
/media/Files/Corporate/Policy-

Frameworks/PublicHealth/Policy/Insert ion-and-Management-of-PeripheralIntravenous-Cannulae/MP38-Insertionand-Management-of-PeripheralIntravenous-Cannulae.pdf

Hidayat, A. A. A., Sukadiono, \& Wijayanti, E. (2020). Predictor factors of phlebitis incidence for children in hospital private in Sidoarjo, Indonesia. Systematic Reviews in Pharmacy. https://doi.org/10.31838/srp.2020.6.3 9

Jannah, I., Suhartono, S., \& Adi, M. (2016). Prevalensi phlebitis pada pasien rawat inap dengan infus di RSUD Tugurejo Semarang. Jurnal Kesehatan Masyarakat Universitas Diponegoro.

Joae Brett Nito, P., Sari Mulia Banjarmasin, S., \& Ahmad Yani, S. (2017). Relationship of age, gender, location insertion and catheter size of incidence phlebitis. Dinamika Kesehatan.

Laudenbach, N., Carie A., B., Klaverkamp, L., \& Hedman-Dennis, S. (2014). Peripheral IV stabilization and the rate of complications in children: An exploratory study. Journal of Pediatric Nursing.

https://doi.org/10.1016/j.pedn.2014.02 .002

Mandal, A., \& Raghu, K. (2019). Study on incidence of phlebitis following the use of pherpheral intravenous catheter. Journal of Family Medicine and Primary Care.

https://doi.org/10.4103/jfmpc.jfmpc_5 59_19

Marleni, L., Novayelinda, R., \& Dewi, Pristiana, A. (2009). Faktor- faktor yang mempengaruhi kejadian ekstravasasi infus pada pasien anak. Jurnal Imiah Ilmu Keperawatan Indonesia.

Nursalam. (2015). Konsep dan Penerapan Metodologi Penelitian Ilmu Keperawatan Edisi 2. In Salemba Medika.

Nyika, M. L., Mukona, D., \& Zvinavashe, M. (2018). Factors contributing to phlebitis among adult patients admitted in the medical-surgical units of a central hospital in Harare, Zimbabwe. Journal of Infusion Nursing. https://doi.org/10.1097/NAN.00000000 00000265

O'Grady, N. P., Alexander, M., Burns, L. A., Dellinger, E. P., Garland, J., Heard, S. O., Lipsett, P. A., Masur, H., Mermel, L. A., Pearson, M. L., Raad, I. I., Randolph, A. G., Rupp, M. E., Saint, S., \& Healthcare Infection Control Practices Advisory Committee (HICPAC). (2011). Guidelines for the prevention of intravascular catheter-related infections. Clinical Infectious Diseases : An Official Publication of the Infectious Diseases 
Society of America. https://doi.org/10.1093/cid/cir257

Potter, P. A., \& Perry, A. G. (2010). Fundamental Keperawatan (7th ed.).

Ray-Barruel, G. (2017). Infection prevention: Peripheral intravenous catheter assessment and care. Australian Nursing $\&$ Midwifery Journal.

Rizky, W. (2016). Analisis faktor yang berhubungan dengan kejadian phlebitis pada pasien yang terpasang kateter intravena di ruang bedah rumah sakit Ar. Bunda Prabumulih. Jurnal Ners Dan Kebidanan Indonesia. https://doi.org/10.21927/jnki.2016.4(2 ). $102-108$

Singh, A. K., Dwivedi, R., \& Ghaharwar, A. P. S. (2018). Risk factors of thrombophlebitis at infusion sites in patients admitted in surgical ward: A prospective observational study International Surgery Journal. https://doi.org/10.18203/23492902.isj20181570

Urbanetto, J. de S., Peixoto, C. G., \& May, T. A. (2016). Incidence of phlebitis associated with the use of peripheral IV catheter and following catheter removal. Revista Latino-Americana de Enfermagem.

https://doi.org/10.1590/15188345.0604.2746

Wayunah, W., Nurachmah, E., \& Mulyono, S. (2013). Pengetahuan perawat tentang terapi infus mempengaruhi kejadian plebitis dan kenyamanan pasien. Jurnal Keperawatan Indonesia. https://doi.org/10.7454/jki.v16i2.12 